\title{
Health Status of Population Living around the Proposed Uranium Mining Area
}

\author{
K. Uma Maheswari and K. Rajeswari* \\ Department of Foods and Nutrition, Post Graduate and Research Centre, PJTSAU, \\ Rajendranagar, Hyderabad-30, Telangana, India \\ *Corresponding author
}

\begin{tabular}{|l|}
\hline Key w o r d s \\
Uranium, Health \\
status, Core zone, \\
Buffer zone
\end{tabular}

\section{Introduction}

The atomic energy programme of our country has gained considerable momentum for increasing the need of energy for the accelerated agricultural and industrial growth during the last five decades (Zahid and Barik, 2004). The Government is committed to appreciable increase in contribution of nuclear power to the total power generation capacity and it has been felt that a balance mix of hydel, coal and nuclear power is must for meeting the long-term power requirement.

The Department of Atomic Energy accordingly, has very strategically designed the nuclear power programme of our country and an immediate goal has been set to produce $20,000 \mathrm{MWe}$ of nuclear power by $2020 \mathrm{AD}$ (Gupta and Sarangi, 2005). Self-reliance in basic raw materials is dominant paradigm of nuclear programme of India. Therefore, the 
growth of uranium industry has shown an extraordinary up-trend during last one decade. The industry is expected to expand further matching with the phenomenal growth of nuclear power generation in the coming years. Apart from supplying the raw material for nuclear fuel, the uranium mining industry in India has a great potential to contribute towards development of infrastructure, mining technology and generate employment opportunity in the nation

The first uranium mine in India was opened at Jadugoda, Jharkand state, where uranium is being mined since the establishment of the Uranium Corporation India Limited (UCIL) in 1967. At present, Uranium is extracted from Jadugoda, Bhatin, Turmadih, Bagjata, Narwapahar and Banduharng mines by the UCIL. Several uranium occurrences have also been found in Andhra Pradesh, India. These include Lambapur-Peddagattu (Fig. 1), Chitrial, Kuppunuru, Tumallapalle, Rachakuntapalle which have significantly contributed towards the uranium reserve base of India (Sinha et al., 1995). To expand the utilization of uranium ore on large scale, UCIL has implementing its operations in mining and processing at LambapurPeddagattu areas, were endowed with huge uranium deposits (Gupta et al., 2004).

Uranium extraction is subject to all of the ethical issues as it can inflict harm on human health and the environment. On the contrary, studies conducted by the scientists of the Environmental Assessment Division of Bhaba Atomic Research Centre, India and the Indian School of mines, Dhanbad, India did not find any cause of concern due to radiation exposure.

It has been reported that more than $50 \%$ of the people present in a public hearing at Seripalle, Nalgonda district, in 2005 opposed to the mining project at Lambapur-Peddagttu. The local lambada tribe opposed to the environmental disturbance and interruptions in their traditional, nature-centric lifestyle that they had followed for centuries. Several NGOs used videos and CDs to show the harmful effects of uranium mining at Jadugoda from the tailing ponds. This also helped in generating opposition to the mining project among the local residents.

In view of this, environmental radioactive studies in and around proposed mining areas was feltextremely useful for establishing baseline data before a large-scale uranium extraction process come into existence. The data helps in estimating the after-effects of mining operations and in taking remedial actions, if necessary. Provision of baseline information also helps to understand the health profile of the people which has potential impact on the natural environment and health condition of the local communities before mining was initiated.

Hence, the present study on health status of population at Lambapur-Peddagattu area where the uranium mining is likely to be initiated was taken up with the objectives of collecting information on mortality, morbidity, mental health indicators, prevalence of cancer, renal diseases, incidence and distribution of communicable, non-communicable diseases and occupational diseases among the people.

\section{Materials and Methods}

The main instrument for collection of household health survey was a structured questionnaire. It was prepared in local language as per the protocol given by the BRNS (Baba Atomic Research in Nuclear Sciences).

The sample size covered was as per the protocol given by the BRNS. The proposed area was divided into three zones with the 
radius of $0-5 \mathrm{~km}, 5-15 \mathrm{~km}$ and $15-30 \mathrm{~km}$ around the Peddagattu- Lambapur area (Fig. 2). The sample selected for the survey was $100 \%$ villages with $100 \%$ population within $0-5 \mathrm{~km}$, $10 \%$ of villages with $100 \%$ households in 5$15 \mathrm{~km}$ and $5 \%$ villages with $100 \%$ households in $15-30 \mathrm{~km}$.

In $0-5 \mathrm{~km}$ core zone around 3 villages with 9 hamlets were identified with total families of 1849 and 7349 population (Fig. 3). The 5$15 \mathrm{~km}$ area was divided into 16 sectors. From all sectors one village with $100 \%$ households covering all the family members were surveyed. In $5-15 \mathrm{~km}$ buffer zone I two (2) sectors were identified with reservoir hence survey was not done (Fig. 4). The $15-30 \mathrm{~km}$ radius area was also divided in 16 sectors (Fig. 5) and from each sector one village was selected for household health survey. Each village was surveyed with $100 \%$ households and population.

The qualified [Auxiliary Nurse Midwifery (ANM)] nursing were selected for collection of data. They are provided with a kit comprised of household health survey schedules, stethoscope, BP apparatus, weighing scale and detachable height measuring rod.

The health camps were organized after the completion of household health survey. In total, 8 health camps were organized in core zone (5), buffer zone I (2) and buffer zone II (1). Independent medical camps were conducted for the remote village's viz. Peddagattu and Lambapur where as in other camps a cluster of villages and hamlets comprising of 2-4 villages/ hamlets were included in each camp.

Before conduct of medical camps, campaigning was done in the concerned villages. Campaigning included distribution of household code number to each family, door to door intimation and distribution of sample collection bottles for urine and sputum to the suspected cases.

The medical camps were organized for all the villagers and most of the patients from in and surrounding villages of venue attended the health camps voluntarily. Prior announcements were made in the respective villages about the medical camps to be organized.

All the patients were thoroughly examined by the doctors. Blood, urine, sputum and Pap smear samples were collected from the patients as prescribed by the doctors for further investigations. The diagnostic tests were carried.

The data was statistically analyzed using methods like mean, median and z-test. Core zone results were compared with buffer zones data. The number or percentage cases viz. tuberculosis, cancer, HIV, pneumonia, congenital diseases were compared with WHO country profile data (WHO, 2011).

\section{Results and Discussion}

The data on health status of population was collected not only by household health survey but also by collection of secondary data from local public health centers as well as medical institutions like mandal health centers, District TB centers and aarogyasri scheme records etc.

Table 1 depicts the percentage of population reported health ailments in 3 zones. Around $26.2 \%$ of population reported health problems in core zone, $45.0 \%$ in buffer zone I and $40.6 \%$ in buffer zone II. The population with health ailments were found significantly $(\mathrm{p}<0.05)$ higher in buffer zone I and buffer zone II compared with core zone. The type of health problems shown in the table were not significantly differing in 3 zones except for minor ailments. 


\section{Congenital malformations}

Among the health problems, congenital malformations accounted $1 \%$ in three zones. The malformations reported are polio, mental retardation, abnormal body parts, dwarfness, dumb and deaf etc.

The results of congenital malformations found in the present study area was in accordance with study on health status of indigenous people around Jadugoda uranium mines in India conducted by Indian Doctors for peace and development (IDPD, 2007; Sonowal and Jojo, 2003). The investigation mentioned that the babies from mothers, who lived near uranium mining operation area, suffered with significantly increased congenital deformities. While $4.49 \%$ mothers living in the study villages reported that children with congenital deformities were born to them, whereas only $2.49 \%$ mothers in reference villages reported the same.

The ministry of social justice, Government of India stipulates that the people with disabilities constitute $3 \%$ of the total population (Ministry of Social Justice, Government of India). This survey also reveals that the people with disabilities (1\%) are relatively lower in core zone compared to buffer zones.

In contrast the animal studies have also reported reduced number of offspring, reduced fetal body weight and length, and an increase in skeletal malformations from oral exposure to uranium in animals (Agency for Toxic Substances and Disease Registry (ATSDR)).

\section{Cancer and renal problems}

No significant difference $(\mathrm{P}>0.05)$ was observed in 3 zones in the prevalence of cancer and renal problems. Percent population reported with cancer and renal problems was found more in both core zone $(0.8 \%)$ and buffer zone I $(0.8 \%)$ compared to buffer zone II $(0.3 \%)$. The type of cancer reported in 3 zone areas were blood cancer, brain cancer, breast cancer, uterus cancer, abdominal cancer and liver cancer. In another study on health impact of release of radioactive elements from Rajasthan atomic power station (RAPS) located at Rawatbhata near Kota in central India conducted in 1991 reported that there has been an increase in the rate of congenital deformities and more cancer deaths in villages near plant. In this study about $0.2 \%, 0.2 \%$ and $0.1 \%$ total of population reported with cancers in core zone, buffer zone I and buffer zone II respectively.

Kidney problems reported by the population included swelling of kidneys, urine infections, pain etc. A study by Zamora et al., (1998) and Kurttio et al., (2005) reported that kidney function is affected in the people who consumed drinking water with elevated uranium concentrations. However, the reported cases may be a representation of subclinical toxicity which will not necessarily lead to kidney failure or overt illness.

The percent distribution of households reported cancer history was not significantly differing $(\mathrm{P}>0.05)$ in 3 zones. The population reported cancer history was $5 \%$ in core zone, $0.6 \%$ in buffer zone I and $0.3 \%$ in buffer zone II. This is also strongly supported by the population who are suffering with cancer at present $(0.2 \%)$ in core zone and buffer zone I compared to buffer zone II (0.1\%) (Fig. 6).

But in accordance to the study by Tripathi et al., the radiation dose from all sources to the people in the villages around the mining complex to be much below the ICRP recommendations and that level is not lead to cancers (Tripathi et al., 2011). The lower consumption of fruits and vegetables increases the total cancer risk (Giri et al., 2010). 
Fig.1 Uranium mining area identified in united Andhra Pradesh state

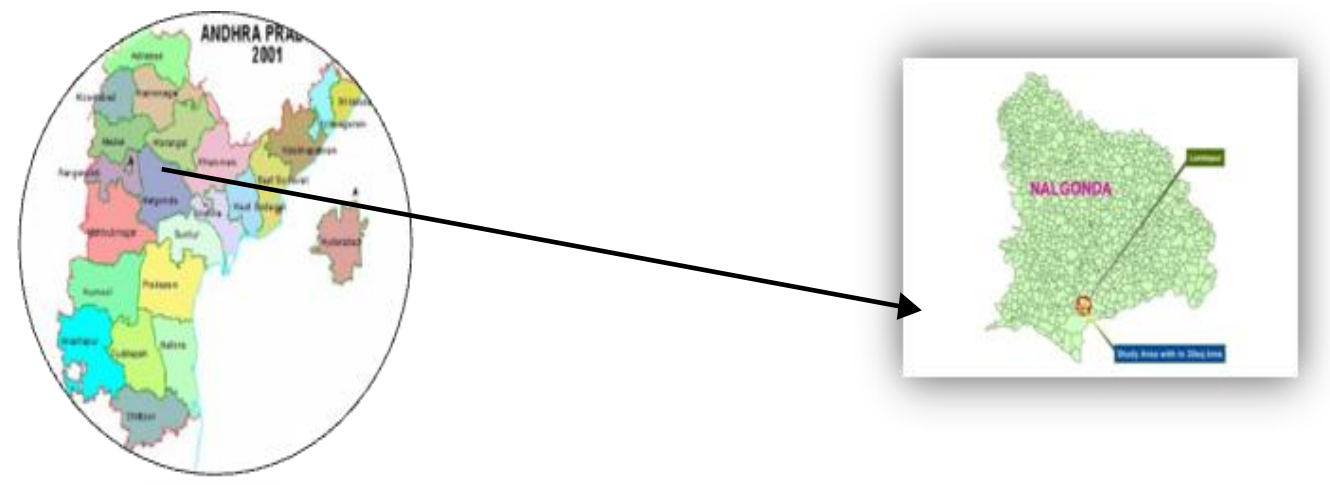

Fig.2 Proposed study area (0-30km zone area) from Lambapur-Pedaagattu

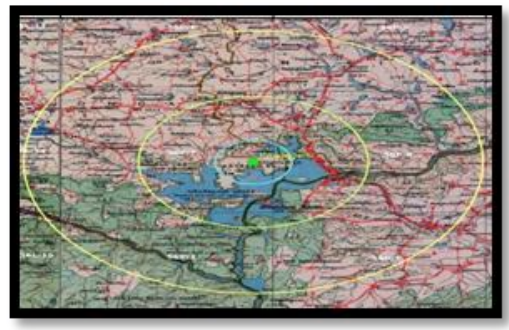

Fig.3 Topo sheet showing villages and hamlets in $0-5 \mathrm{~km}$ core zone

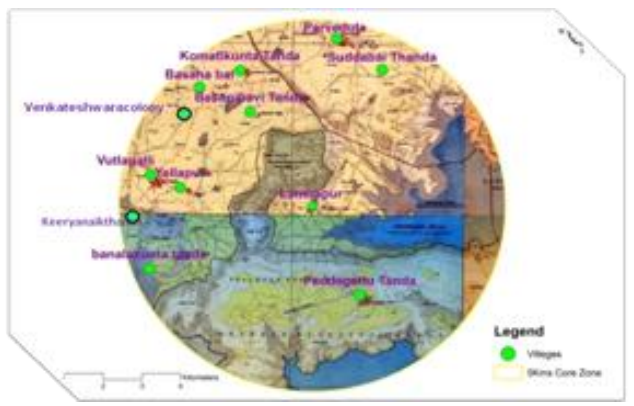

Fig.4 Topo sheet showing villages and hamlets in $5-15 \mathrm{kms}$ buffer zone I

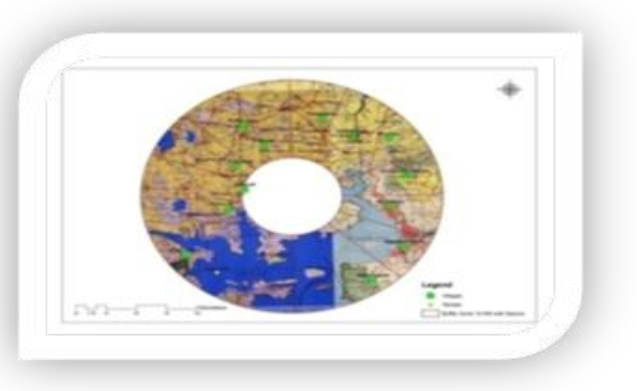


Fig.5 Topo sheet showing villages and hamlets in 15-30kms buffer zone II

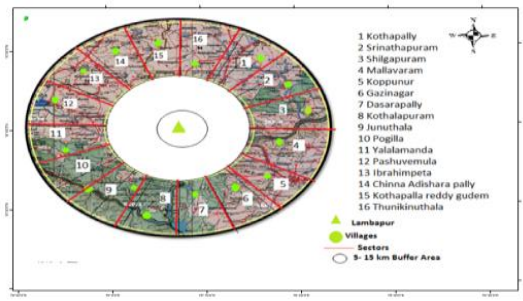

Fig.6 Distribution of households reported cancer history

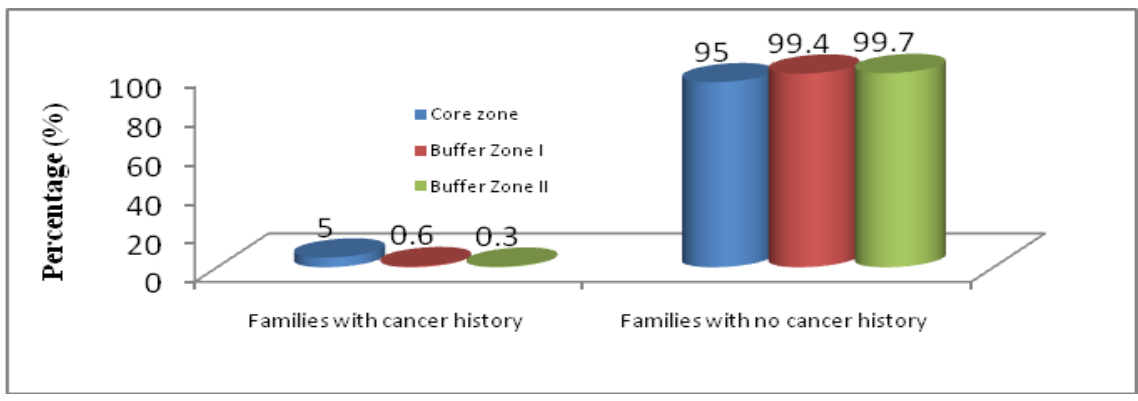

Fig.7 Distribution of population based on incidence of non-communicable diseases

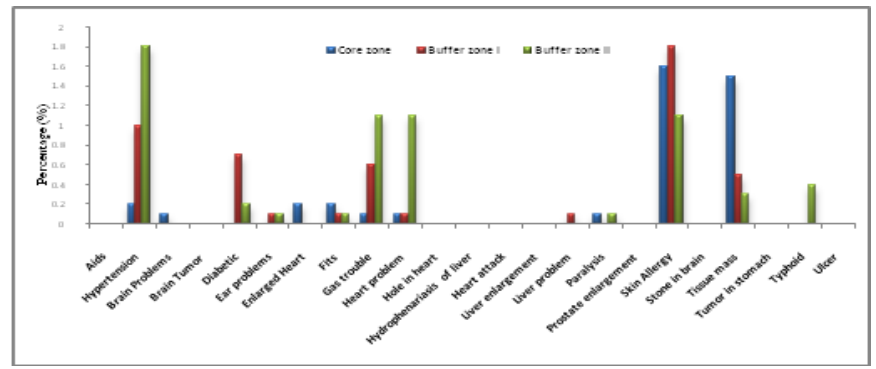

Table.1 Percent incidence of health ailments

\begin{tabular}{|l|c|c|c|c|c|}
\hline \multicolumn{1}{|c|}{ Type of health ailments } & Core zone & Buffer zone I & Buffer zone II & Total \\
\hline Cancer \& Renal problems & $57(0.8)$ & $166(0.8) \mathrm{NS}$ & $47(0.3) \mathrm{NS}$ & $270(0.6)$ \\
\hline Communicable diseases & $65(0.9)$ & $200(1.0) \mathrm{NS}$ & $114(0.7) \mathrm{NS}$ & $379(0.9)$ \\
\hline Congenital malformations & $54(0.7)$ & $199(1.0) \mathrm{NS}$ & $117(0.7) \mathrm{NS}$ & $370(0.8)$ \\
\hline Eye problems & $124(1.7)$ & $423(2.1) \mathrm{NS}$ & $210(1.3) \mathrm{NS}$ & $757(1.7)$ \\
\hline Gynic problems & $56(0.8)$ & $186(0.9) \mathrm{NS}$ & $51(0.3) \mathrm{NS}$ & $293(0.7)$ \\
\hline Minor ailments & $1188(16.2)$ & $6219(31.0) \mathrm{NS}$ & $4854(29.0) * *$ & $12261(27.8)$ \\
\hline Non- Communicable diseases & $301(4.1)$ & $996(5.0) \mathrm{NS}$ & $886(5.3) \mathrm{NS}$ & $2183(4.9)$ \\
\hline Other ailments & $36(0.4)$ & $143(0.7) \mathrm{NS}$ & $95(0.6) \mathrm{NS}$ & $274(0.7)$ \\
\hline Respiratory problems & $43(0.6)$ & $615(3.1) \mathrm{NS}$ & $408(2.4) \mathrm{NS}$ & $1066(2.4)$ \\
\hline Population with health ailments & $1924(26.2)$ & $9147(45.6) * *$ & $6782(40.6) * *$ & $17853(40.5)$ \\
\hline Normal population & $5425(73.8)$ & $10908(54.4) * *$ & $9938(59.4) * *$ & $26271(59.5)$ \\
\hline
\end{tabular}

$\$(. .$.$) number in parenthesis indicates percentages$ NS-Non significant at $0.05 \%$ level

**Significant at $0.05 \%$ level 


\section{Incidence of communicable diseases}

Among the communicable diseases reported by the population tuberculosis was found high in core zone $(0.7 \%)$ whereas fever in buffer zone I $(0.8 \%)$ and buffer zone II $(0.3 \%)$. The reports of Tuberculosis Association and PHCs survey of villages also reported the presence of tuberculosis in 65 persons in the surveyed areas. The sputum and X-ray tests were carried for 130 people during health camps and around 10 people were confirmed with tuberculosis. As per the world health organization country profiles the incidence of tuberculosis per 100,000 population is 185 $(0.18 \%)$.

The Agency for Toxic Substances and Disease Registry Chronic revealed that exposure to radon in humans and animals via inhalation has resulted in respiratory effects (chronic lung disease, pneumonia, fibrosis of the lung, decreased lung function), while animal studies have also reported effects on the blood and a decrease in body weights [Agency for Toxic Substances and Disease Registry (ATSDR)].

\section{Incidence of eye problems}

Higher percentage of population reported poor vision, cataracts, redness of eyes, watery eyes and pain in eyes.

\section{Non communicable diseases}

Skin allergies and tissue masses were the major reported problems among the noncommunicable problems in the population of 3 zones. Tissue masses were usually found on the exposed body parts in adults and children mainly. $1.5 \%, 0.5 \%$ and $0.3 \%$ of people were found with tissue masses in different parts of the body in 3 zones respectively. People replied that the tissue masses were growing with age without any pain.
But exclusively when Carcinoma Embryo Antigen (CEA) cancer screening test were carried for $20 \%$ of the tissue mass cases (30 persons) in core zone, none were found with cancer susceptibility.

However, radium and radon are potent human carcinogens. Radium, via oral exposure, is known to cause lung, bone, head (mastoid air cells), and nasal passage tumors. Radon, via inhalation exposure, causes lung cancer. Studies in uranium miners have shown an increase in lung cancer and tumors of the lymphatic and hematopoietic tissues from inhalation exposure. However, it is not known whether the cancer risk is from uranium itself, or from radon or other confounding factors [Agency for Toxic Substances and Disease Registry (ATSDR)].

Respiratory problems like asthma, breathing problem and cough and cold and pneumonia were found more in buffer zone I and buffer zone II compared to core zone (Fig. 7).

\section{Gynic problems}

Wound in uterus, tumor in breast, breast pain and abdomen pain were the major gynic problem reported by women in the mining area. These were also found more in women living in core zone and buffer zone I area compared to buffer zone II area.

\section{Minor ailments}

Pain in legs and hands, back pain, knee pain, headache, stomach pain, body pain, shoulder pain, nerves pain, chest pain, body pain were the major complaints reported by the population in 3 zones.

\section{Expose to X-rays}

Significant difference $(\mathrm{P}<0.05)$ was not observed in 3 zones among the population 
who were exposed to X-rays. Higher percentage of population $(7.3 \%)$, exposed to $\mathrm{x}$-ray were found in core zone compared to buffer zones.

The major reasons expressed by the majority of population in 3 zones for expose to X-rays were fractures, stomach pain, back pain, knee pain, fever, leg pain, headache, chest pain tuberculosis, pneumonia, etc.

The morbidities, general weakness and minor ailments are prevailing in the population living around the uranium proposed mining area. These morbidities are not addressing the health problems properly. Drinking unsafe water, improper nutrition resulting from lack of knowledge, education and income could lead these problems. The incidence of cancer was very lower, only $0.2 \%$ and $0.1 \%$ cancer cases were found in core zone and buffer zone I in buffer zone II respectively.

Majority of the respondents could not show the reports of diagnostic tests and treatments details and assumed occurrence of the tissue mass in various body parts as cancer. However, the diagnostic tests carried out for 36 cases of tissue mass (biopsy, carcinoembrio antigen (CEA, CA 125, CA15.3, CA 19.9) for screening of cancer revealed negative results. However, viral infections, malaria, tuberculosis and skin allergies are widespread in the population. The unhygienic personal habits and practices of rural population are commonly found in the rural population.

The prevalence of anemia in both male and female was also found could be attributed to malnutrition and malaria. The WBC deferential count was also found to be normal across the population. The results concealed no statistical difference in the health status of population living in the 3 zones around the proposed uranium mining area.

\section{References}

Agency for Toxic Substances and Disease Registry (ATSDR). Toxicological Profile for Uranium (Update). Public Health Service, U.S. Department of Health and Human Services, Atlanta, GA. 1999.

Giri, S., Singh, G., Jha, V.N. and Tripathi, R.M. 2010. Ingestion of U (nat), 226Ra, 230Th and 210Po in Vegetables by Adult Inhabitants of Bagjata Uranium Mining Area, Jharkhand, India. Radioprotection, Vol.45, No.2, pp. 183199.

Gupta R. and Sarangi A.K. 2005. Uranium production and raw materials for the nuclear fuel cycle - Supply and demand, economics, the environment and energy security from IAEA symposium Vienna, Austria. Jun. 20-24, 11-15.

Gupta R., Kundu K. and Sarangi A.K. 2004. Uranium Mining, Milling And Tailings Disposal - Best Practices from National Seminar on Environmental and sociological Implications of Mining (Coal, Limestone and Uranium) and exploitation of Oil and natural gas in North - East India. North - East India Council for Social Science, Shillong, Jun. 5-6, 1-14.

IDPD, 2007. Black magic of Uranium at Jadugoda: study on Health Status of indigenous people around Jadugoda Uranium mines in India.

Kurttio, P., Auvinen, A., and Selonen, L., Komulainen, H., Leino, A. and Saha, H., 2005. Bone as a possible target of chemical toxicity of natural uranium in drinking water. Environmental Health Perspective 113:68- 72.

Ministry of Social Justice, Government of India

Sinha R.M., Shrivastava V.K., Sarma G.V.G. and Parthesarthy T.N. 1995. Geological favorability for unconformity related 
Uranium deposits in the northern parts of the Cuddapah Basin, evidence from Lambapur Uranium occurrence, Andhra Pradesh, India. Exp. Res. At Miner, 8, 11-126.

Sonowal, C.J. and Jojo, S.K. 2003. Radiation and tribal health in Jadugoda: the contention between science and sufferings. Studies of Tribes and Tribals, Vol. 1, No. 2, pp. 111-126.

Tripathi, R. M., Sahoo, S. K., Jha, V. N., Kumar, R., Shukla, A. K., Puranik, V. D. and Kushwaha, H. S., Radiation dose to members of public residing around uranium mining complex, Jaduguda,
Jharkhand, India. Radiation Protection Dosimetry, 2010, 147, 1-8. 9.

World Health Organization, 2011

Zahid H. and Barik S.K. 2004. Development and Environment: Development of Geo Its Impacts on Environment and Man of North East India, Regency publication, New Delhi, 105.

Zamora, M.L., Tracy, B.L., Zielinski, J.M., Meyerhof, D.P. and Moss, M.A., 1998. Chronic ingestion of uranium in drinking water: A study of Kidney Bioeffects in humans. Toxicol. Sci. 43: 31- 45 .

\section{How to cite this article:}

Uma Maheswari, K. and Rajeswari, K. 2018. Health Status of Population Living around the Proposed Uranium Mining Area. Int.J.Curr.Microbiol.App.Sci. 7(01): 1560-1568. doi: https://doi.org/10.20546/ijcmas.2018.701.189 